Canadian University Music Review

Revue de musique des universités canadiennes

\title{
Elaine Keillor, ed. The Canadian Musical Heritage-Le Patrimoine musical canadien. Vol. I: Piano Music 1. Ottawa: Canadian Musical Heritage Society, 1983, XXIV, 246 pp.
}

\section{Gordana Lazarevich}

\author{
Numéro 5, 1984
}

URI : https://id.erudit.org/iderudit/1014012ar

DOI : https://doi.org/10.7202/1014012ar

Aller au sommaire du numéro

Éditeur(s)

Canadian University Music Society / Société de musique des universités canadiennes

ISSN

0710-0353 (imprimé)

2291-2436 (numérique)

Découvrir la revue

Citer ce compte rendu

Lazarevich, G. (1984). Compte rendu de [Elaine Keillor, ed. The Canadian Musical Heritage — Le Patrimoine musical canadien. Vol. I: Piano Music 1. Ottawa: Canadian Musical Heritage Society, 1983, XXIV, 246 pp.] Canadian

University Music Review / Revue de musique des universités canadiennes, (5), 320-323. https://doi.org/10.7202/1014012ar

All Rights Reserved (C) Canadian University Music Society / Société de musique des universités canadiennes, 1984
Ce document est protégé par la loi sur le droit d'auteur. L’utilisation des services d'Érudit (y compris la reproduction) est assujettie à sa politique d'utilisation que vous pouvez consulter en ligne.

https://apropos.erudit.org/fr/usagers/politique-dutilisation/ 
Elaine KeILlor, ed. The Canadian Musical Heritage-Le Patrimoine musical canadien. Vol. I: Piano Music 1. Ottawa: Canadian Musical Heritage Society, 1983, XxIV, $246 \mathrm{pp}$.

Over the past quarter century or so the study of Canada's musical heritage has developed in varying embryonic stages. Pioneering works such as Helmut Kallmann's A History of Music in Canada 1534-1914 (1960), Willy Amtmann's Music in Canada 1600-1800 (1975), and, more recently, Clifford Ford's Canada's Music: An Historical Survey (1982) have attempted to document in relatively broad measure the history and development of the Canadian musical heritage. Recent regional archival work, such as Dale McIntosh's A Documentary History of Music in Victoria, Vol. I: 1850-1899 (1981), is of inestimable value to the student of local and provincial history. The publication of the Encyclopedia of Music in Canada (1981) represents a major and important step in the assembly and presentation of information about all aspects of Canadian musical culture of the past and present. While these sources all excel in the quality of information presented, collectively they serve merely as a beginning to scholarly investigation of Canada's musical culture and traditions.

A nation may have a rich musical heritage, but until that heritage is disclosed through modern publication it is not a living entity. One can verbalize about music and its social functions only up to a certain point, after which music must be played and heard in order for the significance of a tradition to be grasped. A living musical tradition that elevates itself above mere historical fact can exist only if the music is accessible to everyone: student, teacher, scholar, the public at large.

There has been a dearth of available musical material. A vast body of early Canadian music remains in manuscript. Despite the considerable percentage of extant music published at the time of its composition, both manuscripts and early printed music are currently mere historical artifacts preserved in the National Library in Ottawa and other libraries throughout the world and thus for the most part not easily accessible to the performing musician. The anthology of early Canadian printed music recently launched by the Canadian Musical Heritage Society is a pioneering effort to fill this void. Aimed at including music from the earliest examples of composition in Canada up to the early twentieth century, the goal of the series is to bring to life some of the music of this country's past by making it available in published form.

Each volume of the projected twenty-five will be devoted to a specific genre. The material is to be distributed into such categories as music for piano, organ, chamber ensemble, orchestra and band, music for solo voice, hymn tunes, choral music, opera and operetta. While each volume will assign one editor who will be responsible for 
the collection, organization, and editing of material, the primary motivating force behind the entire project has been the Editorial Advisory Committee. Helmut Kallmann, John Beckwith, Frederick Hall, Clifford Ford, Elaine Keillor, and Lucien Poirier are responsible for the supervision of all aspects of the editorial procedures and for the general standards of the anthology. They are the core of a Board of Directors that also includes Claude Beaudry, Marcien Ferland, Brian Flemming, Richard Johnston, Dale McIntosh, and Gilles Potvin.

The first volume-Piano Music l-edited by Elaine Keillor, has recently been published. The first of three volumes of piano music, it is to be followed by Sacred Choral Music I (edited by Clifford Ford) and Songs I, to English Texts (edited by Frederick Hall). It is proposed to release the volumes at the rate of two per year.

The music of the first volume is reproduced both in facsimile and, on occasion, in a modern hand-written copy when the illegibility of the original necessitates clarification. Facsimile reproduction is gaining popularity, given the hard economic realities of music publishing today. Prime examples of the use of the technique are the publications of the Garland Publishing Company of New York, which is able to make available in print large segments of the eighteenth- and nineteenthcentury European repertoire (opera and symphony in particular). Facsimile reproduction is a perfectly acceptable and even desirable reproduction technique and the only way to publish material in an economical way. Its adoption for the Musical Heritage Society series is a practical means of making available affordable editions.

The first volume of the series is a practical edition, designed for the performer. The introductory material, printed in both official languages, is divided into three sections: editorial aims and methods; short discussions of the historical background to the pieces contained in the volume; and critical notes presenting vital statistics for each composition as well as explanations of any editorial changes and additions to the individual works. The introduction also contains interesting and valuable descriptions, many drawn from contemporary sources, of the social significance of various dance forms and other genres of piano pieces included in the anthology.

The compositions have been carefully chosen by the editor to present a chronological sample of works reflective of the predominant keyboard genres of the time. Dance music and marches intermingle with such idiomatic keyboard pieces as variations, études, nocturnes, and parlor pieces. The practical value of the volume cannot be overstated, for it presents the piano student and the amateur music lover with offbeat Canadian repertoire and offers study pieces to the college student interested in the history of music in Canada; it can only serve to stimulate further research.

The piano compositions presented in the first volume must be perceived in the context of life in a country undergoing rapid settlement 
and expansion. To a certain extent the pieces reflect the social functions of music within an immigrant society. If they project a seeming lack of musical sophistication when compared to the virtuoso piano repertoire of early- and mid-nineteenth-century Europe, it is because they reflect the conditions of music-making in a new society-a dearth of pianos, for example, and of professional educational facilities. The editor, Elaine Keillor, is to be complimented on her selection of pieces for inclusion in the volume, a choice that reflects her considerable knowledge of the field. One looks forward to the other two volumes of piano music which will contain compositions reflective of the new trends of the latter part of the last century by composers such as Alexis Contant, W.O. Forsyth, Clarence Lucas, and Gene Branscombe.

Quite apart from its practical, pedagogical, and historical value, the entire Canadian Musical Heritage series sets a precedent for similar undertakings in the future. It is important to note, therefore, the weaknesses of the first volume. There are basically two categories of objections: one pertains to the quality of the printing, the other to editorial inconsistencies. Weaknesses in both areas tend to lend the edition a non-professional quality unworthy of a series of this magnitude.

The quality of the printing is the most serious problem. With very few exceptions the printing throughout the entire first volume is poor, in some places seriously affecting the clarity and legibility of the scores (see, for example, pages 135, 138-39, and 201). Although the reprinting in this volume of the occasional title page of an original edition adds historical interest, the quality of the print varies from one example to another. Occasional ink smudges alternate with lines that are too pale (as in pp. $1 \& 15$ ). While it is true that the modern reprint can only be as good as the quality of the original, modern reproductions should be based only on the best quality originals if the reprinted examples are to serve their purpose. The degree of smudged ink varies from such examples as seen on pages $6-7(\mathrm{~mm} .8,15-16,29)$ to blacked-in flags (p. 7, mm. 33-48), blurred passages (pp. 18-19), and staff lines that are poorly visible due to the paleness of the ink. The occasional uneven margins (p. 160, for example) marr the aesthetic appearance of the volume.

The second category of objections pertains to editorial inconsistencies which show up in a number of ways. Square brackets, for example, indicative of editorial corrections, are used in different places with different thicknesses of ink. This distracts from the clarity of interpretation, leading the performer to wonder whether each set of brackets carries a different meaning. Three instances of such inconsistency are singled out: (a) on page 69 , measures 50 and 54, the righthand flat sign is enclosed in half-brackets delineated in thin ink; (b) on page 27, measures 70-72, the sharp sign in the left hand is enclosed in full brackets in uneven thin and thick ink; (c) on page 27 , 
measures 92 and 94, the sharp sign above the left hand carries fulllength brackets in thin ink. In a further comparison of sizes and shapes of square brackets, those on page 78 , for example, are much more inconspicuous as an aid in reading the page than the ones on page 26 which detract from the clarity of the page.

A corrigendum has been loosely inserted into the volume indicating corrections to seven mistakes in the first fourteen pages of the text. This fact in itself is suggestive of a degree of carelessness in proofreading. The inclusion of such an unbound page would seem to defeat its purpose, as the page is almost certain to fall out at the first use of the volume.

To the uninitiated these comments may seem trivial. However, consistency in the use of editorial symbols and minute detail of orthography constitute the basis of good editorial practice. Editing music is a discipline that deals with such minutae, since they are the guides to clarity and legibility in a modern edition. With careful proofreading, more editorial consistency, and better printing facilities the production quality can be improved in future volumes. This first volume may well be seen as an experimental effort. Given the caliber of scholars and musical personalities involved in the project, one is confident of the quality of the future volumes in the series.

When a nation has acquired enough confidence to assess and display its musical heritage, it is one sign that the cultural life of the nation has embarked upon its period of maturity. The Canadian Musical Heritage society is fulfilling a vital function by displaying our musical past to us. And curiosity about the past is an essential ingredient of our concern for the future.

Gordona Lazarevich

ClifFord Ford, ed. The Canadian Musical Heritage-Le Patrimoine musical canadien. Vol. II: Sacred Choral Music 1. Ottawa: Canadian Musical Heritage Society, 1984, xxix, 238 pp.

Sacred Choral Music I, the second volume in the Canadian Musical Heritage Series, contains sacred choral music from the Roman Catholic and Protestant traditions of the late seventeenth to nineteenth centuries. The works are mostly for SATB choir with organ accompaniment, sometimes with soloists, but there are also a few pieces for men's and some for women's (or boy's) chorus. The volume is carefully edited on the whole, with only a few minor errors in the musical text (e.g., p. 47, m. 123, beat 3, left-hand ledger line missing; p. 145, m. 34, right hand read B-flat not G-flat). In addition to editing the works, Ford has in a few instances completed or supplied organ accompaniments.

The Roman Catholic section begins with some seventeenth-century 